University of Wollongong

Research Online

Faculty of Science - Papers (Archive)

Faculty of Science, Medicine and Health

$1-1-2006$

\title{
Endogenous nitrogen excretion by red kangaroos (Macropus rufus): Effects of animal age and forage quality
}

Adam J. Munn

University of New South Wales, amunn@uow.edu.au

Terence J. Dawson

University of New South Wales

Ian D. Hume

University of Sydney

Follow this and additional works at: https://ro.uow.edu.au/scipapers

Part of the Life Sciences Commons, Physical Sciences and Mathematics Commons, and the Social and Behavioral Sciences Commons

\section{Recommended Citation}

Munn, Adam J.; Dawson, Terence J.; and Hume, Ian D.: Endogenous nitrogen excretion by red kangaroos (Macropus rufus): Effects of animal age and forage quality 2006, 424-436.

https://ro.uow.edu.au/scipapers/445

Research Online is the open access institutional repository for the University of Wollongong. For further information contact the UOW Library: research-pubs@uow.edu.au 


\title{
Endogenous nitrogen excretion by red kangaroos (Macropus rufus): Effects of animal age and forage quality
}

\author{
Abstract \\ Red kangaroos (Macropus rufus) are large ( $>20 \mathrm{~kg}$ ) herbivorous marsupials common to arid and semiarid \\ Australia. The population dynamics of red kangaroos are linked with environmental factors, operating \\ largely through juvenile survival. A crucial period is the young-at-foot (YAF) stage, when juveniles have \\ permanently left the mother's pouch but still take milk from a teat in the pouch. Forage quantity and \\ quality have been implicated in drought-related mortalities of juvenile kangaroos. Here we compared how \\ forage quality affected nitrogen $(\mathrm{N})$ intake and excretion by YAF, weaned, and mature, non-lactating \\ female red kangaroos. On high-quality forage ( chopped lucerne hay, Medicago sativa) low in neutral- \\ detergent fiber $(43 \%+/-1 \%)$ and high in $\mathrm{N}(2.9 \%+/-0.1 \%)$, YAF and weaned kangaroos had ideal growth \\ rates and retained $460-570 \mathrm{mg}$ dietary $\mathrm{N} \mathrm{kg}(-0.75) \mathrm{d}(-1)$. But on poor-quality forage ( chopped oaten hay, \\ Avena sativa) high in neutral-detergent fiber $(64 \%+/-1 \%)$ and low in $\mathrm{N}(0.9 \%+/-0.1 \%)$, YAF and weaned \\ kangaroos could not sustain growth and were in negative $\mathrm{N}$ balance at $-103+/-26 \mathrm{mg}$ and $-57+/-31 \mathrm{mg}$ \\ $\mathrm{N} \mathrm{kg}(-0.75) \mathrm{d}(-1)$, respectively. Notably, the YAF kangaroos excreted $64 \%$ of their truly digestible $\mathrm{N}$ intake \\ from forage as nondietary fecal N (NDFN). By weaning age, the situation had improved, but the juveniles \\ still lost $40 \%$ of their truly digestible $\mathrm{N}$ intake as NDFN compared with only $30 \%$ by the mature females. \\ Our findings support field observations that forage quality, and not just quantity, is a major factor \\ affecting the mortality of juvenile red kangaroos during drought.

\section{Disciplines} \\ Life Sciences | Physical Sciences and Mathematics | Social and Behavioral Sciences

\section{Publication Details} \\ Munn, A. J., Dawson, T. J. \& Hume, I. D. (2006). Endogenous nitrogen excretion by red kangaroos \\ (Macropus rufus): Effects of animal age and forage quality. Physiological and Biochemical Zoology, 79 \\ (2), 424-436.
}




\section{Endogenous Nitrogen Excretion by Red Kangaroos (Macropus rufus): Effects of Animal Age and Forage Quality}

\author{
Adam J. Munn ${ }^{1, \dagger}$ \\ Terence J. Dawson ${ }^{1}$ \\ Ian D. Hume ${ }^{2}$ \\ ${ }^{1}$ School of Biological, Earth, and Environmental Sciences, \\ University of New South Wales, Sydney, New South Wales \\ 2052, Australia; ${ }^{2}$ School of Biological Sciences, University of \\ Sydney, New South Wales 2006, Australia
}

Accepted 8/11/2005; Electronically Published 1/30/2005

\section{ABSTRACT}

Red kangaroos (Macropus rufus) are large (>20 kg) herbivorous marsupials common to arid and semiarid Australia. The population dynamics of red kangaroos are linked with environmental factors, operating largely through juvenile survival. A crucial period is the young-at-foot (YAF) stage, when juveniles have permanently left the mother's pouch but still take milk from a teat in the pouch. Forage quantity and quality have been implicated in drought-related mortalities of juvenile kangaroos. Here we compared how forage quality affected nitrogen (N) intake and excretion by YAF, weaned, and mature, nonlactating female red kangaroos. On high-quality forage (chopped lucerne hay, Medicago sativa) low in neutral-detergent fiber $(43 \% \pm 1 \%)$ and high in $\mathrm{N}(2.9 \% \pm 0.1 \%)$, YAF and weaned kangaroos had ideal growth rates and retained 460$570 \mathrm{mg}$ dietary $\mathrm{N} \mathrm{kg} \mathrm{d}^{-0.75} \mathrm{~d}^{-1}$. But on poor-quality forage (chopped oaten hay, Avena sativa) high in neutral-detergent fiber $(64 \% \pm 1 \%)$ and low in $\mathrm{N}(0.9 \% \pm 0.1 \%)$, YAF and weaned kangaroos could not sustain growth and were in negative $\mathrm{N}$ balance at $-103 \pm 26 \mathrm{mg}$ and $-57 \pm 31 \mathrm{mg} \mathrm{N} \mathrm{kg}{ }^{-0.75}$ $\mathrm{d}^{-1}$, respectively. Notably, the YAF kangaroos excreted $64 \%$ of their truly digestible $\mathrm{N}$ intake from forage as nondietary fecal $\mathrm{N}$ (NDFN). By weaning age, the situation had improved, but the juveniles still lost $40 \%$ of their truly digestible $\mathrm{N}$ intake as

\footnotetext{
* Abbreviations: DM, dry matter; DMI, dry matter intake; EUN, endogenous urinary nitrogen; MNR, maintenance nitrogen requirement; NDFN, nondietary fecal nitrogen; PPE, permanent pouch exit; TDNI, truly digestible nitrogen intake; YAF, young-at-foot.

${ }^{\dagger}$ Corresponding author. Present address: School of Biological Sciences, Institute of Wildlife Research, Heydon-Laurence Building, University of Sydney, New South Wales 2006, Australia.
}

Physiological and Biochemical Zoology 79(2):424-436. 2006. (C) 2006 by The University of Chicago. All rights reserved. 1522-2152/2006/7902-5035\$15.00
NDFN compared with only $30 \%$ by the mature females. Our findings support field observations that forage quality, and not just quantity, is a major factor affecting the mortality of juvenile red kangaroos during drought.

\section{Introduction}

Red kangaroos (Macropus rufus) are the largest extant marsupial herbivore and are adapted for life in Australia's arid and semiarid interior (Dawson 1995). They are highly sexually dimorphic. In unharvested areas, mature, breeding males usually weigh $60-80 \mathrm{~kg}$, though they can exceed $100 \mathrm{~kg}$. Mature females are smaller and usually weigh $25-35 \mathrm{~kg}$, though they occasionally reach $40 \mathrm{~kg}$ (Dawson 1995). Like all macropodid marsupials (kangaroos and wallabies; family Macropodidae), red kangaroos are able to digest fibrous vegetation by fermentation in a large, colon-like forestomach (Hume 1974, 1999). Generally, they prefer young green vegetation low in plant fiber (i.e., the structural carbohydrates cellulose and hemicellulose and also lignin/cutin) but high in protein (nitrogen $[\mathrm{N}]$ ) and easily digestible cell contents (Dawson et al. 1975; Barker 1987; Dawson and Ellis 1994). Australia's arid regions, however, are among the driest and most unpredictable of any continent (Low 1979), and red kangaroos experience considerable variation in feed quantity and quality (Shepherd 1987; Dawson and Ellis 1994; Moss and Croft 1999). During dry periods, fresh plant growth is quickly eaten, and mature, dry grasses predominate. These grasses are characteristically high in hard to digest fiber and low in N, but they provide up to $90 \%$ of the adult red kangaroo diet during dry conditions (Barker 1987; Dawson and Ellis 1994). The extent to which juvenile red kangaroos can utilize such forage is uncertain, but juvenile mortality is typically high during drought (Dawson 1995; McCullough and McCullough 2000). Only after several rain periods, when highquality forage is plentiful, does juvenile survival improve, leading to significant population recruitment (Newsome et al. 1967; Bayliss 1985; Robertson 1986; Dawson 1995).

As with other marsupials, newborn red kangaroos are extremely small, weighing ca. $800 \mathrm{mg}$ (Sharman et al. 1964; Frith and Calaby 1969). The tiny hairless neonate makes its way from the mother's cloaca to a large, well-developed pouch, characteristic of macropodid marsupials. By around $190 \mathrm{~d}$ old, at about $2 \mathrm{~kg}$, the young is fully furred and ventures out of the pouch for short periods, returning regularly to the pouch, pre- 
sumably for warmth and safety (Sharman et al. 1964; Frith and Calaby 1969). By 230-250 d old, the young red kangaroo permanently leaves the mother's pouch, becoming a young-at-foot (YAF; body mass 4-5 kg). YAF kangaroos forage in association with their mothers but also continue to take milk from the mother's pouch, using the same teat used during pouch life. Forage intake by YAF increases markedly at this stage, though they are not fully weaned until about $360 \mathrm{~d}$ old and 10-12 kg body mass (Sharman et al. 1964; Frith and Calaby 1969).

The red kangaroo age/size class most impacted by poor environmental conditions is from permanent pouch exit (PPE) until shortly after weaning (Newsome et al. 1967; Robertson 1986). This stage coincides with the transition from a milkbased diet to vegetation, and limited ability to digest poorquality, high-fiber forage (Demment and Van Soest 1985; Cork 1994; Munn and Dawson 2003a, 2003b) may explain their vulnerability to drought. Moreover, during prolonged or severe drought, red kangaroo mothers usually cease lactating, making YAF solely reliant on available forage. In this study, we further explore how forage quality might affect the growth and survival of juvenile red kangaroos beyond PPE. Specifically, we have quantified the impact of high-fiber, low- $\mathrm{N}$ forage on $\mathrm{N}$ excretion and $\mathrm{N}$ balance of juvenile and adult red kangaroos. It is important to note, however, that these results were generated as part of a larger study investigating the digestive physiology and energetics of juvenile and adult red kangaroos (Munn and Dawson 2003a). As such, we used only two diets that varied in both energy and $\mathrm{N}$ content. Typically, experiments to study relationships between $\mathrm{N}$ intake and excretion employ a series of diets varying only in $\mathrm{N}$ content (Robbins 1993). Nonetheless, there was sufficient variation in $\mathrm{N}$ intake by our red kangaroos to provide reasonable estimates of $\mathrm{N}$ intake- $\mathrm{N}$ excretion relationships. Consequently, our results provide evidence that $\mathrm{N}$ excretion might be a key factor affecting the survival of juvenile red kangaroos during drought.

\section{Material and Methods}

\section{Experimental Animals}

Juveniles. Six juvenile red kangaroos (four females, two males) were taken from their mothers shortly before PPE. They were aged from foot and tail lengths (Sharman et al. 1964) and treated for parasites (internal and external) using Ivermectin (0.2 $\mathrm{mg} \mathrm{kg}^{-1}$; large animal Ivomec, Merck Sharp \& Dohme, Granville, Australia). The young kangaroos were reared in artificial pouches (Williams and Williams 1999) until they reached the age of PPE, about 250 d (Sharman et al. 1964). Five weeks before experimentation, the animals were transferred to our laboratory animal house and maintained in pens $(4,300 \mathrm{~mm} \times 1,200 \mathrm{~mm} \times 2,500 \mathrm{~mm})$ under a $12 \mathrm{~L}: 12 \mathrm{D}$ cycle. The now YAF kangaroos were weighed at the beginning of each week $( \pm 0.05 \mathrm{~kg})$. Rabbit pellets (Gordon's Specialty Stock Feeds, Yanderra, Australia), kangaroo cubes (Doust and Rab- bidge, Forbes, Australia), a lucerne/wheat bran mix (Kensington Produce, Sydney, Australia), and water were available ad lib. This diet was supplemented with Digestelact (Digestelact Low Lactose, Sharpe Laboratories, Sydney), a low-lactose milk powder commonly used for hand-rearing orphaned marsupials (Williams and Williams 1999), made to full strength (125 g 900 $\mathrm{mL}^{-1} \mathrm{H}_{2} \mathrm{O}$ ). During nonexperimental periods, a daily supplement of $100 \mathrm{~mL}$ of Digestelact was offered to the YAF. Milk intakes by red kangaroo young have not been reported, but on this intake of Digestelact plus forage and pellets, the YAF red kangaroos maintained growth rates comparable to those reported by Sharman et al. (1964) and Frith and Calaby (1969).

Milk was withheld from the YAF according to the diet treatments described below. Milk intake was reduced over time until it was eliminated at normal weaning age, ca. $360 \mathrm{~d}$. During the rearing process, juveniles were exposed to fresh grass and soil and to the feces of adult red kangaroos to facilitate infection by the microbes needed for the proper functioning of the kangaroo forestomach.

Feeding trials were carried out when the average age ( \pm SEM) of the YAF was $302 \pm 6 \mathrm{~d}$ and their average body mass was $6.4 \pm 0.2 \mathrm{~kg}$. Trials were repeated using the same animals after they had been fully weaned and were, on average, $394 \pm 7 \mathrm{~d}$ and $10.9 \pm 0.3 \mathrm{~kg}$ body mass.

Adults. Six tame nonlactating adult female red kangaroos from a captive colony were maintained under housing conditions identical to those of the juveniles. Kangaroo cubes, the lucerne/ wheat bran mix, and water were available ad lib. Five of the adult females were known to be at least 5 yr old; the other was $4 \mathrm{yr}$ old. Average body mass of the adult females during the experiments was $25.8 \pm 1.6 \mathrm{~kg}$.

Diets and Feeding Regimens. Two forages of different fiber levels were used. Chopped lucerne (alfalfa; Medicago sativa) hay was considered high-quality forage, being comparatively low in neutral-detergent fiber and high in N. Chopped oaten (Avena sativa) hay was considered poor-quality forage, being higher in fiber and low in $\mathrm{N}$ content (Table 1). Apparent dry matter digestibility of lucerne and oaten hays by adult red kangaroos was ca. 55\% and 45\%, respectively (McIntosh 1966; Hume 1974). Some animals initially refused the chopped oaten hay. Subsequently, the diet was always lightly sprayed $(<5 \% \mathrm{v} / \mathrm{w})$ with unsweetened apple juice (Golden Circle, Sydney, Australia) to increase palatability. The contribution of the juice to energy and $\mathrm{N}$ intakes was assessed as negligible.

In preliminary trials, YAF red kangaroos offered only chopped oaten hay (i.e., without a milk supplement) eventually did not eat. This treatment was therefore omitted from the main trials. Only by using a milk supplement $\left(80 \mathrm{~mL} \mathrm{~d}^{-1}\right.$ of full-strength Digestelact) were we able to assess the YAF capabilities when fed chopped oaten hay. Milk was fed at 0900 hours and 1800 hours at $40 \mathrm{~mL}$ per feed. The importance of 
Table 1: Composition of the chopped lucerne and oaten hays and Digestelact milk powder

\begin{tabular}{lrrc}
\hline & Lucerne Hay & Oaten Hay & Digestelact \\
\hline DM (\% initial mass) & $92.2 \pm .6$ & $92.4 \pm .4$ & $99.0 \pm .0$ \\
Ash (\% DM) & $9.6 \pm .3$ & $5.8 \pm .1$ & $4.84 \pm .0$ \\
Energy (kJ g $\left.{ }^{-1} \mathrm{DM}\right)$ & $16.7 \pm .2$ & $15.7 \pm .4$ & $21.9 \pm .2$ \\
Energy (kJ mL milk $\left.{ }^{-1}\right)$ & & & $(2.7 \pm .03)$ \\
N (\% DM) & $2.9 \pm .07$ & $.89 \pm .09$ & $4.5 \pm .01$ \\
N (mg mL milk $\left.{ }^{-1}\right)$ & & & $(5.6 \pm .01)$ \\
Neutral detergent fiber (\% DM) & $43.4 \pm .8$ & $64.3 \pm .5$ & $\ldots$ \\
Acid detergent fiber (\% DM) & $32.4 \pm 1.0$ & $36.0 \pm .3$ & $\ldots$ \\
Lignin/cutin (\% DM) & $6.2 \pm .2$ & $3.4 \pm .1$ & $\ldots$ \\
Soluble cell contents (\% DM) & $56.6 \pm .8$ & $35.7 \pm .5$ & $\ldots$ \\
\hline
\end{tabular}

Note. $\mathrm{DM}=$ dry matter. Results are means $\pm \mathrm{SE}$. Values in parentheses are for Digestelact at normal dilution (i.e., $124 \mathrm{~g} \mathrm{DM} \mathrm{L}^{-1}$ milk).

the milk supplement to forage digestion by YAF red kangaroos was described by Munn and Dawson (2003b).

Diet order was established by randomly allocating three YAF to a starting diet of chopped lucerne or oaten hay (with milk). The YAF were then assigned a fixed regimen of lucerne followed by chopped oaten hay with milk or vice versa. After weaning, feeding trials were repeated using the same animals, maintaining the diet order initially established. Importantly, weaned red kangaroos did not receive any milk supplement. Similarly, three adult females were randomly assigned to a starting diet of chopped lucerne followed by oaten hay, the order being reversed for the remaining adults. This fixed, counterbalanced design was used to minimise carryover effects caused by diet order or animal age (Zar 1999).

\section{Experimental Procedure}

Feeding trials were conducted in a temperature-controlled room $\left(25^{\circ} \mathrm{C}\right)$ on a $12 \mathrm{~L}: 12 \mathrm{D}$ cycle, with lights on at $0600 \mathrm{~h}$. Adult and juvenile kangaroos were housed individually in metabolism cages $(1,245 \mathrm{~mm} \times 960 \mathrm{~mm} \times 1,670 \mathrm{~mm})$ with mesh floors. Feces and urine passed to a collection tray beneath each cage. Collection trays consisted of a fine wire mesh on which feces and any spilled feed were trapped, allowing urine to flow to the tray bottom where it drained continuously into polyethylene volumetric flasks. Urine collection flasks contained 1$2 \mathrm{~mL}$ glacial acetic acid and vegetable oil to prevent bacterial growth and evaporation, respectively. Feed and water containers were attached to the outside of each cage to minimise feed spillage. Feed and water containers and waste collection trays were cleaned daily with demineralised water. During the preliminary and feeding trials, herbage was offered to the kangaroos at twice the previous day's level of voluntary intake.

YAF and weaned kangaroos were allowed $5 \mathrm{~d}$ to acclimate to their metabolism cage before a preliminary trial commenced. Preliminary trials were conducted for at least $5 \mathrm{~d}$ or until feed intake was stable, after which time a 5-d feeding trial commenced. During each trial, feed refusals and feces were collected quantitatively and bulked over the $5 \mathrm{~d}$ and stored frozen. YAF and weaned kangaroos were weighed $( \pm 0.05 \mathrm{~kg})$ at the same time each day throughout the preliminary and feeding trials. At the end of each trial, animals received their usual diet (i.e., water, kangaroo cubes, rabbit pellets, lucerne/bran mix) ad lib. for at least $10 \mathrm{~d}$; YAF also received $100 \mathrm{~mL}$ Digestelact $\mathrm{d}^{-1}$.

Adult red kangaroos were allowed at least $10 \mathrm{~d}$ to acclimate to their experimental diet and metabolism cage (i.e., preliminary trial). After feed intake had stabilised, a 5-d feeding trial commenced. Adult kangaroos were weighed $( \pm 0.05 \mathrm{~kg})$ at the beginning of the preliminary and experimental trials and again at the end of the experimental trial. After each experimental trial, adults received their usual diet (water, kangaroo cubes, lucerne/bran mix) ad lib. for at least $10 \mathrm{~d}$.

\section{Analysis of Samples}

Samples of feed offered together with all feed refused and all feces were collected daily and stored frozen. Feedstuffs and feces were later thawed, and subsamples (ca. 20\% wet mass) were prepared for analysis by air drying in a forced convection oven at $50^{\circ} \mathrm{C}$ (Robertson and Van Soest 1981) for $48 \mathrm{~h}$. Further subsamples were dried at $90^{\circ} \mathrm{C}$ for an additional $24 \mathrm{~h}$, but there was no change in dry matter (DM) contents. Dried samples were ground through a 1-mm mesh in a Wiley Mill (Arthur Thomas, Scientific Apparatus, Philadelphia). Ash contents of dried, ground feedstuffs (including Digestelact milk powder) and feces were determined in duplicate by dry ashing 0.5-g samples at $550^{\circ} \mathrm{C}$ overnight in a Thermolyne Muffle Furnace (model 62700; Dubuque, IA).

Neutral detergent fiber, acid detergent fiber, and lignin contents of lucerne and oaten hays were determined in duplicate from 0.5-g samples using an ANKOM fiber analyzer (model 220; ANKOM Technology, Fairport, NY), according to Van 


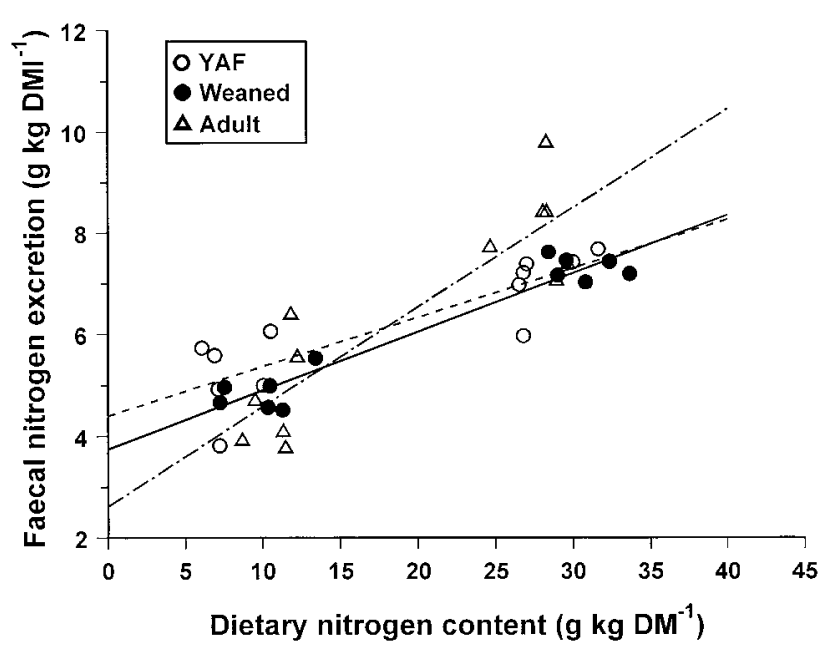

Figure 1. Fecal $\mathrm{N}$ excretion ( $\mathrm{g} \mathrm{kg}$ dry matter intake ${ }^{-1}$ ) as a function of dietary $\mathrm{N}$ content ( $\mathrm{g} \mathrm{kg}$ dry matter $\left.{ }^{-1}\right)$. Dashed line, YAF; $y=$ $0.10 x+4.4( \pm 0.4), r^{2}=0.70, F=27, \mathrm{df}=11, P<0.001$. Solid line, weaned; $y=0.12 x+3.8( \pm 0.2), r^{2}=0.93, F=133, \mathrm{df}=11, P<$ 0.001. Dashed and dotted line, adult; $y=0.20 x+2.6( \pm 0.7), r^{2}=$ $0.78, F=35$, df $=11, P<0.001$.

Soest et al. (1991). Energy contents of dried ground feedstuffs were determined by combusting duplicate subsamples of $0.7 \mathrm{~g}$ in a ballistic bomb calorimeter (Gallenkamp, model CB-375; Gallenkamp, United Kingdom) using a benzoic acid standard for calibration every 25 samples. $\mathrm{N}$ content of feedstuffs and feces was determined in duplicate by total combustion of approximately 0.2-g samples in a Leco CHN-1000 elemental analyzer (Leco, St. Joseph, MI).

Urine subsamples (ca. $80 \mathrm{~mL}$ ) were collected daily and frozen. Urine was later thawed in a refrigerator and prepared by centrifuging subsamples $(20 \mathrm{~mL})$ at $1,600 \mathrm{~g}$ for $20 \mathrm{~min}$, removing any feed or feces contamination. Urinary $\mathrm{N}$ content was determined in duplicate by total combustion of approximately $0.3 \mathrm{~g}$ of wet sample in a Leco $\mathrm{CHN}-1000$ elemental analyzer (Leco).

\section{Data Analysis}

Some kangaroos showed considerable diet selection during the feeding trials. Intake of dietary $\mathrm{N}$ was calculated as

$$
\begin{aligned}
\mathrm{N} \text { intake }= & (\mathrm{N} \text { in } \mathrm{FO} \times \text { mass } \mathrm{FO}) \\
& -(\mathrm{N} \text { in } \mathrm{FR} \times \text { mass } \mathrm{FR})
\end{aligned}
$$

where FO is feed offered, FR is feed refused, $\mathrm{N}$ is in $\mathrm{g} \mathrm{g}^{-1} \mathrm{DM}$, and mass is in g DM. Apparent digestibilities (\%) of DM and $\mathrm{N}$ were calculated as

$$
\frac{\text { intake }- \text { fecal output }}{\text { intake }} \times 100 \text {, }
$$

where intake and fecal output are in $\mathrm{g} \mathrm{d}^{-1}$. Apparent DM digestibility was then used to estimate digestible DM intakes. $\mathrm{N}$ balance was measured as the difference between dietary $\mathrm{N}$ intake and fecal plus urinary N output (Robbins 1993).

Nondietary fecal $\mathrm{N}$ (NDFN) was estimated by plotting $\mathrm{N}$ content of feces against the $\mathrm{N}$ content of consumed feed (Bosshardt and Barnes 1946; Robbins 1993). A significant regression allows an estimate NDFN ( $\mathrm{g} \mathrm{kg} \mathrm{DMI}^{-1}$ ) by extrapolating to zero $\mathrm{N}$ intake (Fig. 1); fecal $\mathrm{N}$ at this point is taken to be solely of animal origin, mainly cellular debris, undigested enzymes, and bacteria (Hume 1999). NDFN is also known as metabolic fecal N (Robbins 1993), but in herbivores, not all nondietary fecal N is of metabolic origin (Foley and Hume 1987; Smith and Green 1987). Truly digestible N intake (TDNI) was calculated as (Bradshaw and Bradshaw 2001)

$$
\text { TDNI }=\text { dietary } \mathrm{N} \text { intake }-(\text { total fecal } \mathrm{N}-\mathrm{NDFN}) .
$$

Endogenous urinary N (EUN) was estimated by plotting urinary $\mathrm{N}$ excretion against TDNI (Robbins 1993; Bradshaw and Bradshaw 2001). A significant regression allows an estimate of EUN by extrapolating to zero $\mathrm{N}$ intake (Fig. 2).

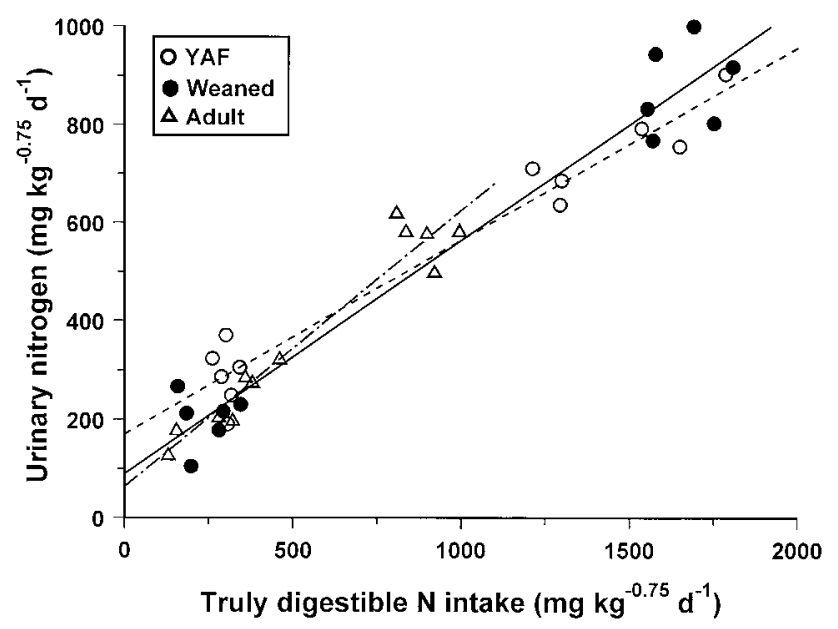

Figure 2. Urinary $\mathrm{N}\left(\mathrm{mg} \mathrm{kg}^{-0.75} \mathrm{~d}^{-1}\right)$ as a function of TDNI $\left(\mathrm{g} \mathrm{kg}^{-0.75}\right.$ $\left.\mathrm{d}^{-1}\right)$. Dashed line, YAF; $y=0.39 x+170.3( \pm 29.4), r^{2}=0.95, F=$ $204, \mathrm{df}=11, P<0.001$. Solid line, weaned; $y=0.47 x+89.3( \pm 38.4)$, $r^{2}=0.95, F=219, \mathrm{df}=11, P<0.001$. Dashed and dotted line, adult; $y=0.56 x+63.2( \pm 29.5), r^{2}=0.93, F=142, \mathrm{df}=11, P<0.001$. 


\section{Statistical Analysis}

Although the method of choice for statistical comparisons was ANCOVA with body mass as the covariate, the YAF and weaned kangaroos were the same animals, and hence the data sets were not independent. Also, it was not logistically feasible to include greater numbers of such large animals in the study. These constraints meant that the use of ANCOVA resulted in overly complex comparisons with small numbers of replicates and limited statistical power. Instead, repeated-measures ANOVA was used to compare within- and between-group data from YAF, weaned, and adult red kangaroos. As noted, nonindependence of the YAF and weaned kangaroos prevented their combined analysis with adult data (Zar 1999). Therefore, YAF and weaned kangaroos were compared using two-way repeated-measures ANOVA with two levels of within-group factors (diet and age). YAF and weaned data were then compared separately with those of adult red kangaroos using two-way repeated-measures ANOVA. Statistical outcomes for the within-YAF, -weaned, and -adult kangaroo data were the same across all betweengroup comparisons (e.g., outcomes for within-YAF data were the same when YAF were compared with weaned or adult kangaroos). For this reason, results are presented as if they were one data set, even though they were tested independently.

Data on intake and output are presented as $\mathrm{g} \mathrm{d}^{-1}$ or as $\mathrm{mg}$ $\mathrm{kg}^{-0.75} \mathrm{~d}^{-1}$ for comparison with other studies. The most appropriate exponent for intraspecific comparisons often differs from 0.75 (Hume 1999), but there were insufficient data to establish this relationship in this study. Therefore, the exponent of 0.75 , which was shown by Hayssen and Lacy (1985) to be the most appropriate for comparisons of basal metabolic rate among marsupials, was used for both intra- and interspecific comparisons.

Assumptions for ANOVA were tested using the KolmogorovSmirnov test for normality $(\alpha=0.05)$ and Levene's test for homogeneity of variances $(\alpha=0.05)$. To achieve normality and/or homogeneity, $\log (+1)$ transformations were applied to the following data sets: DMI ( $\mathrm{g} \mathrm{d}^{-1}$; YAF vs. adults), digestible DMI ( $\mathrm{g} \mathrm{d}^{-1}$; YAF vs. weaned; YAF vs. adults), $\mathrm{N}$ intake ( $\mathrm{g} \mathrm{d}^{-1}$; $\mathrm{mg} \mathrm{kg}{ }^{-0.75} \mathrm{~d}^{-1}$; YAF vs. adult; weaned vs. adult), TDNI ( $\mathrm{g} \mathrm{d}^{-1}$; $\mathrm{mg} \mathrm{kg}{ }^{-0.75} \mathrm{~d}^{-1}$; YAF vs. weaned; YAF vs. adults), and urinary $\mathrm{N}$ output ( $\mathrm{g} \mathrm{d}^{-1}$; YAF vs. weaned; weaned vs. adults). Some data sets, however, could not be normalised and were compared using a Friedman's test (a nonparametric ANOVA for repeated measures; Zar 1999). Data sets compared using Friedman's test were as follows: apparent digestibility of DM (\%; YAF vs. adult; YAF vs. weaned), DMI ( $\mathrm{g} \mathrm{kg}^{-0.75} \mathrm{~d}^{-1}$; YAF vs. weaned), digestible DMI ( $\mathrm{g} \mathrm{kg}^{-0.75} \mathrm{~d}^{-1}$; YAF vs. weaned), apparent $\mathrm{N}$ digestibility (\%; YAF vs. weaned; YAF vs. adult; weaned vs. adult), urinary and fecal $\mathrm{N}$ output and $\mathrm{N}$ balance $\left(\mathrm{mg} \mathrm{kg} \mathrm{kg}^{-0.75} \mathrm{~d}^{-1}\right.$; YAF vs. weaned; YAF vs. adult; weaned vs. adult), and NDFN (\% total fecal N; YAF vs. weaned; weaned vs. adult).

Significant differences detected by ANOVA were further in- vestigated using a Tukey's honest significant differences (HSD) post hoc test. Significant differences detected by Friedman's test were investigated using equation (11.3) from Zar (1999), with standard error adjusted for repeated measures. Regression analyses were performed using the least squares method (Zar 1999). ANOVAs, Tukey's HSD, and Friedman's tests were performed using Minitab for Windows 12.1 (1998; Minitab, State College, PA). Z-tests were used to determine whether $\mathrm{N}$ balance in the YAF, weaned, and adult red kangaroos were significantly different from 0 (Zar 1999) and were performed using Minitab for Windows 12.1 .

\section{Results}

\section{Dry Matter Intake and Digestion}

YAF red kangaroos ingested almost $60 \%$ as much DM $\left(\mathrm{g} \mathrm{d}^{-1}\right)$ from the high-quality diet (chopped lucerne hay) as did the mature, nonreproductive females (Table 3), despite being just $25 \%$ of the mature female's body mass (Table 2 ). By weaning age, DMI $\left(\mathrm{g} \mathrm{d}^{-1}\right)$ by the juvenile red kangaroos had increased and was not significantly different from that of adults, even though the weaned kangaroos were still less than half the body mass of mature females (Table 2). Apparent DM digestibility of chopped lucerne hay was similar across all of the age classes, varying within the narrow range of $56 \%-59 \%$ (Table 3 ). Consequently, patterns of digestible DMI by the red kangaroos on chopped lucerne hay largely followed those for gross DMI (Table 3 ). On an allometric basis (i.e., per $\mathrm{kg}^{0.75}$ ), however, digestible DMI by the YAF and weaned kangaroos on chopped lucerne hay was 1.5-1.8 times that by mature females, but they were not significantly different from each other (Table 3 ).

On the poor-quality chopped oaten hay diet, DMI $\left(\mathrm{g} \mathrm{d}^{-1}\right)$ by the mature females was not significantly lower than that on chopped lucerne (Table 3). In contrast, DMI by the YAF and weaned kangaroos on chopped oaten hay was less than half that on chopped lucerne $(P<0.01)$. The apparent DM digestibility of the oaten hay diet was similar across all age classes ( $P>0.05$ ), ranging between $43 \%$ and $45 \%$ (Table 3 ). However, the YAF on this diet also received artificial milk $\left(80 \mathrm{~mL} \mathrm{~d}^{-1}\right)$, because preliminary trials indicated that the YAF would not have survived on chopped oaten hay alone (see Munn and Dawson 2003b). Assuming a milk-DM digestibility of $95 \%$ (Penning et al. 1977; Roy 1980; Ternouth et al. 1985), the apparent digestibility of the DM from the chopped oaten hay forage (without milk) by the YAF was just $34 \% \pm 2 \%$, significantly lower than that by weaned or adult kangaroos (Table 3).

\section{Dietary N Intake, Apparent N Digestibility, and N Balance}

Intake of $\mathrm{N}$ by the juvenile and adult red kangaroos largely reflected differences in their overall feed intakes. On the chopped lucerne hay, $\mathrm{N}$ intake $\left(\mathrm{g} \mathrm{d}^{-1}\right)$ by the YAF was $60 \%$ of 
Table 2: Changes in body mass by young-at-foot (YAF), weaned, and adult red kangaroos fed chopped lucerne and oaten hays

\begin{tabular}{|c|c|c|c|}
\hline & YAF & Weaned & Adult \\
\hline \multicolumn{4}{|c|}{ Initial body mass $(\mathrm{kg})$ : } \\
\hline Lucerne hay & $6.4 \pm .5^{\mathrm{Z}}$ & $10.8 \pm .3^{Y}$ & $25.8 \pm 1.5^{\mathrm{x}}$ \\
\hline Oaten hay & $6.1 \pm .3^{\mathrm{Z}}$ & $10.9 \pm .5^{\mathrm{Y}}$ & $25.7 \pm 1.6^{\mathrm{X}}$ \\
\hline \multicolumn{4}{|c|}{ Mass change $\left(\mathrm{g} \mathrm{d}^{-1}\right)$ : } \\
\hline Lucerne hay & $43 \pm 9^{\mathrm{X}, * * \star}$ & $55 \pm 11^{\mathrm{X}, * * *}$ & $.0 \pm 16^{\mathrm{X}}$ \\
\hline Oaten hay & $-32 \pm 14^{\mathrm{x}}$ & $-33 \pm 14^{\mathrm{x}}$ & $-61 \pm 30^{\mathrm{x}}$ \\
\hline \multicolumn{4}{|c|}{ Mass change ( $\%$ initial): } \\
\hline Lucerne hay & $3.3 \pm .67^{\mathrm{A}, \star * *}$ & $2.6 \pm .47^{\mathrm{A}, \star *}$ & $.1 \pm .31^{\mathrm{B}}$ \\
\hline Oaten hay & $-2.3 \pm .96^{\mathrm{A}}$ & $-1.5 \pm .65^{\mathrm{A}}$ & $-1.2 \pm .54^{\mathrm{A}}$ \\
\hline
\end{tabular}

Note. Within a row, means \pm SEM bearing different superscripts are significantly different (A, B,

$P<0.05 ; \mathrm{X}-\mathrm{Z}, P<0.01)$. Asterisks indicate significant differences between diets within ages.

** $P<0.01$.

*** $P<0.001$.

that by mature females (Table 4). As with DMI $\left(\mathrm{g} \mathrm{d}^{-1}\right)$, weaned juveniles ingested an amount of dietary $\mathrm{N}\left(\mathrm{g} \mathrm{d}^{-1}\right)$ that was not significantly different from that by mature females (Table 4). The apparent digestibility of $\mathrm{N}$ from chopped lucerne hay did not differ significantly between the YAF, weaned, or mature female kangaroos and ranged between $71 \%$ and $76 \%$ (Table 4 ).

On average, the YAF, weaned, and mature female kangaroos on chopped lucerne hay were in positive $\mathrm{N}$ balance, retaining 1.9-3.4 $\mathrm{g} \mathrm{N} \mathrm{d}^{-1}$, the values being significantly greater than 0 in each case (YAF $Z=5.98$; weaned $Z=11.16$; adult $Z=$ 5.93; $P<0.01)$. On an allometric basis, the YAF and weaned kangaroos retained 2.4- and 3.0-fold more dietary $\mathrm{N}\left(\mathrm{mg} \mathrm{kg}^{-0.75}\right.$ $\mathrm{d}^{-1}$ ), respectively, than the mature females (Table 4). Moreover, on chopped lucerne hay, YAF and weaned kangaroos showed significant increases in body mass, but the mature females did not (Table 2).

The chopped oaten hay forage contained considerably less $\mathrm{N}$ than that found in chopped lucerne (Table 1). Consequently, along with lower overall feed intakes (Table 3), the YAF, weaned, and mature female red kangaroos fed chopped oaten hay had $\mathrm{N}$ intakes significantly lower than those on chopped lucerne by as much as $70 \%-85 \%$ (Table 4 ). Within each age class, the apparent digestibility of $\mathrm{N}$ from the chopped oaten hay diet was significantly lower than that from chopped lucerne $(P<$ 0.001; Table 4). Apparent $\mathrm{N}$ digestibility by the YAF, weaned, and mature female kangaroos on chopped oaten hay were similar, varying between $50 \%$ and $57 \%$ (Table 4 ). However, as noted above, the YAF also received a small amount of artificial milk with the chopped oaten hay. Assuming a milk-N digestibility of 95\% (Penning et al. 1977; Roy 1980; Ternouth et al. 1985), the apparent digestibility of $\mathrm{N}$ by the YAF from the oaten forage alone was just 33\% $\pm 7 \%$, significantly lower than that by the weaned or mature female kangaroos $(P<0.05$; Table 4$)$.

The mature female kangaroos on chopped oaten hay maintained $\mathrm{N}$ balance $\left(\mathrm{g} \mathrm{d}^{-1}\right)$ at levels that were not significantly different from $0(Z=-1.44, P=0.15)$. On the other hand, $\mathrm{N}$ balance on chopped oaten hay was significantly less than 0 in YAF $(Z=-2.6, P<0.01)$ and tended toward significance in weaned kangaroos $(Z=-1.87, P=0.06$; Table 4$)$. This was consistent with the YAF and weaned kangaroos losing significant body mass on this diet (Table 2).

\section{Fecal $N$ Loss and Truly Digestible N Intake}

Fecal $\mathrm{N}$ output (g kg DMI ${ }^{-1}$ ) was positively and significantly related to $\mathrm{N}$ content $\left(\mathrm{g} \mathrm{kg} \mathrm{DM}^{-1}\right)$ of the feed consumed by the YAF, weaned, and mature female kangaroos (Fig. 1). Extrapolating to zero $\mathrm{N}$ intake, we found that excretion of NDFN by the YAF was equivalent to $4.4 \pm 0.4 \mathrm{~g} \mathrm{~N} \mathrm{~kg} \mathrm{DMI}^{-1}$, compared with $3.8 \pm 0.2$ and $2.6 \pm 0.7 \mathrm{~g} \mathrm{~N} \mathrm{~kg} \mathrm{DMI}^{-1}$ by the weaned and adult red kangaroos, respectively. Regression slopes for the YAF and weaned kangaroos did not differ significantly $\left(t_{2}=1.9\right.$, $\mathrm{df}=20, P>0.05)$, but each was significantly different from that of adults (adult vs. YAF $t_{2}=3.7, \mathrm{df}=20, P<0.001$; adult vs. weaned $\left.t_{2}=2.9, \mathrm{df}=20, P<0.01\right)$. Thus, only the NDFN (i.e., $y$-intercept) from the YAF and weaned kangaroos could be statistically compared (because they had equivalent slopes); they were not significantly different $\left(t_{2}=2.1\right.$, df $=21, P<$ $0.05)$.

Forage quality had a significant impact on the proportion of fecal $\mathrm{N}$ lost as NDFN. On the chopped lucerne hay, $62 \%$ of the YAF fecal N was NDFN, compared with $46 \%$ for the weaned kangaroos and 33\% for the mature females (Table 5). On the chopped oaten hay, NDFN losses by the YAF, weaned, and adult kangaroos increased by 20\%-30\% (Table 5), becoming the major route for fecal $\mathrm{N}$ loss. Consequently, TDNI by the YAF, weaned, and mature females on chopped oaten hay was significantly lower than that on chopped lucerne (Table 5). This was most notable in the YAF, especially when the contribution of milk- $\mathrm{N}$ was taken into account. Assuming a milk-N digest- 
Table 3: Dry matter (DM) intake, digestion, and excretion by young-at-foot (YAF), weaned, and adult red kangaroos fed chopped lucerne and oaten hays

\begin{tabular}{|c|c|c|c|}
\hline & YAF & Weaned & Adult \\
\hline \multicolumn{4}{|l|}{ DMI $\left(\mathrm{g} \mathrm{d}^{-1}\right)$ : } \\
\hline Lucerne hay & $233 \pm 23^{\mathrm{B}, * \star}\left({ }^{*}\right)$ & $370 \pm 14^{\mathrm{A}, * * *}$ & $414 \pm 38^{\mathrm{A}}$ \\
\hline Oaten hay (from forage) ${ }^{\mathrm{a}}$ & $105 \pm 10^{\mathrm{C}}\left(95 \pm 10^{\mathrm{C}}\right)$ & $176 \pm 23^{\mathrm{B}}$ & $345 \pm 47^{\mathrm{A}}$ \\
\hline \multicolumn{4}{|l|}{ Fecal DM output $\left(\mathrm{g} \mathrm{d}^{-1}\right)$ : } \\
\hline Lucerne hay & $103 \pm 9^{\mathrm{B}, * * *}$ & $151 \pm 10^{\mathrm{A}, * * *}$ & $183 \pm 27^{\mathrm{A}}$ \\
\hline Oaten hay & $64 \pm 10^{\mathrm{C}}$ & $105 \pm 17^{\mathrm{B}}$ & $201 \pm 27^{\mathrm{A}}$ \\
\hline \multicolumn{4}{|c|}{ Apparent DM digestibility (\%): } \\
\hline Lucerne hay & $56 \pm .6^{\mathrm{A}, * * *}(* * *)$ & $59 \pm 1^{\mathrm{A}, * * *}$ & $57 \pm 3^{\mathrm{A}, * * *}$ \\
\hline Oaten hay (from forage) ${ }^{\mathrm{a}}$ & $40 \pm 3^{\mathrm{A}}\left(34 \pm 2^{\mathrm{B}}\right)$ & $42 \pm 3^{\mathrm{A}}$ & $42 \pm 1^{\mathrm{A}}$ \\
\hline \multicolumn{4}{|l|}{ Digestible DMI $\left(\mathrm{g} \mathrm{d}^{-1}\right)$ : } \\
\hline Lucerne hay & $130 \pm 14^{\mathrm{Y}, * * *}\left({ }^{* * *}\right)$ & $219 \pm 6^{\mathrm{X}, * * *}$ & $231 \pm 14^{\mathrm{X}}$ \\
\hline Oaten hay (from forage) ${ }^{\mathrm{a}}$ & $40 \pm 2^{Z}\left(31 \pm 1^{Z}\right)$ & $71 \pm 6^{\mathrm{Y}}$ & $144 \pm 20^{x}$ \\
\hline \multicolumn{4}{|l|}{ Digestible DMI $\left(\mathrm{g} \mathrm{kg}^{-.75} \mathrm{~d}^{-1}\right)$ : } \\
\hline Lucerne hay & $32 \pm 2^{\mathrm{B}, * * *}(* * *)$ & $37 \pm 1^{\mathrm{B}, * * *}$ & $21 \pm 2^{\mathrm{A}}$ \\
\hline Oaten hay (from forage) ${ }^{\mathrm{a}}$ & $10 \pm .2^{\mathrm{A}}\left(8 \pm .2^{\mathrm{B}}\right)$ & $12 \pm 1^{\mathrm{A}}$ & $13 \pm 2^{\mathrm{A}}$ \\
\hline
\end{tabular}

Note. DMI $=$ dry matter intake. Within a row, means \pm SEM bearing different superscripts are significantly different (A-C, $P<0.05 ; \mathrm{X}-\mathrm{Z}, P<0.01$ ). Asterisks indicate significant differences between diets within ages.

${ }^{a}$ Apparent DM digestibility and DMIs from forage were estimated assuming a milk-DM digestibility of $95 \%$.

** $P<0.01$.

*** $P<0.001$.

ibility of 95\%, TDNI from forage alone by the YAF kangaroos was just $182 \pm 45 \mathrm{mg} \mathrm{kg}^{-0.75} \mathrm{~d}^{-1}$, significantly lower than the $243 \pm 30$ and $271 \pm 43 \mathrm{mg} \mathrm{kg}^{-0.75} \mathrm{~d}^{-1}$ ingested by the weaned and mature female kangaroos, respectively (Table 5).

\section{Endogenous Urinary $N$}

On an allometric basis, there was a significant positive relationship between urinary $\mathrm{N}$ excretion $\left(\mathrm{mg} \mathrm{kg} \mathrm{kg}^{-0.75} \mathrm{~d}^{-1}\right)$ and TDNI (mg kg ${ }^{-0.75} \mathrm{~d}^{-1}$; Fig. 2). Regression slopes relating urinary $\mathrm{N}$ and TDNI did not differ significantly between the YAF and weaned kangaroos $\left(t_{2}=1.9, \mathrm{df}=20, P>0.05\right)$ or between the weaned and adult kangaroos $\left(t_{2}=1.5, \mathrm{df}=20, P>0.05\right)$. There was, however, a significant difference between the YAF and mature females $\left(t_{2}=3.4, \mathrm{df}=20, P<0.01\right)$. Extrapolating to zero $\mathrm{N}$ intake, EUN ( $y$-intercept) by the YAF and weaned kangaroos averaged $170 \pm 29$ and $89 \pm 38 \mathrm{mg}$ truly digestible $\mathrm{N} \mathrm{kg}^{-0.75} \mathrm{~d}^{-1}$, respectively, and were not significantly different $\left(t_{2}=0.3\right.$, df $\left.=21, P>0.05\right)$. EUN by the mature females averaged $63 \pm 30 \mathrm{mg}$ truly digestible $\mathrm{N} \mathrm{kg}^{-0.75} \mathrm{~d}^{-1}$ and was not significantly lower than that by the weaned kangaroos $\left(t_{2}=\right.$ 0.95 , df $=21, P>0.05$ ), but it could not be statistically compared with that by the YAF because of their differing slopes.

\section{Discussion}

Adult red kangaroos are sexually dimorphic, and this is reflected in their levels of feed intake on good-quality, chopped lucerne hay. The mature females in our study were older than $4 \mathrm{yr}$ and had typical body masses of 25-30 kg. Mature males, on the other hand, can attain average body masses of $60-80 \mathrm{~kg}$ by 15 yr of age (Dawson 1995). Our mature females were not lactating and ingested half as much chopped lucerne hay (414 g DM $\mathrm{d}^{-1}$; Table 3) as did mature male red kangaroos (823 g DM $\mathrm{d}^{-1} ; n=3$, body mass $=62 \pm 5 \mathrm{~kg}$; McIntosh 1966). Apparent digestibility of DM from chopped lucerne hay by our females was identical to that by McIntosh's (1966) males, averaging $56 \%$. Thus, on an allometric basis (i.e., per $\mathrm{kg}^{0.75}$ ), digestible DMI by our mature female kangaroos on chopped lucerne hay was identical to that by mature males (McIntosh 1966), at $21 \pm 2 \mathrm{~g} \mathrm{~kg}^{-0.75} \mathrm{~d}^{-1}$ (Table 3). Hume (1974) reported higher intakes of chopped lucerne hay by smaller, younger male red kangaroos (29.2 $\mathrm{g} \mathrm{kg}^{-0.75} \mathrm{~d}^{-1} ; n=3$, body mass $=27-33 \mathrm{~kg}$ ), probably because these still growing males required additional energy and nutrients for growth. Munn and Dawson (2003a) showed that, in red kangaroos, growth energy requirements have a significant impact on overall feed intake. The YAF and weaned red kangaroos in this study were growing rapidly and had digestible DMIs $\left(\mathrm{g} \mathrm{kg}^{-0.75} \mathrm{~d}^{-1}\right.$ ) on chopped lucerne hay significantly greater than that by mature, nonlactating females (Table 3).

In addition to their extra energy demands for growth, young mammals generally have additional $\mathrm{N}$ (protein) requirements for tissue and organ development compared with adults. Consequently, on similar, good-quality forage, juveniles usually have mass-specific and allometrically related $\mathrm{N}$ intakes greater than those of adults (Brody 1945; Robbins 1993). Thus, on the 
Table 4: Nitrogen (N) digestion and balance by young-at-foot (YAF), weaned, and adult red kangaroos fed chopped lucerne and oaten hays

\begin{tabular}{|c|c|c|c|}
\hline & YAF & Weaned & Adult \\
\hline \multicolumn{4}{|l|}{$\mathrm{N}$ intake $\left(\mathrm{g} \mathrm{d}^{-1}\right)$ : } \\
\hline Lucerne hay & $6.6 \pm .8^{\mathrm{Y}, * * *}\left({ }^{* * *}\right)$ & $11.3 \pm .4^{\mathrm{X}, * * *}$ & $11.6 \pm 1.1^{\mathrm{X}, \star \star \star}$ \\
\hline Oaten hay (from forage) ${ }^{\mathrm{a}}$ & $1.3 \pm .1^{\mathrm{Z}}\left(.82 \pm .1^{\mathrm{Z}}\right)$ & $1.7 \pm .2^{\mathrm{Y}}$ & $3.7 \pm .5^{\mathrm{x}}$ \\
\hline \multicolumn{4}{|l|}{$\mathrm{N}$ intake $\left(\mathrm{g} \mathrm{kg}^{-.75} \mathrm{~d}^{-1}\right)$ : } \\
\hline Lucerne hay & $1.62 \pm .11^{\mathrm{Y}, * * *}(* * *)$ & $1.90 \pm .05^{\mathrm{Y}, \star * *}$ & $1.02 \pm .10^{\mathrm{X}, \star * \star}$ \\
\hline Oaten hay (from forage) ${ }^{\mathrm{a}}$ & $.33 \pm .01^{\mathrm{A}}\left(.21 \pm .02^{\mathrm{B}}\right)$ & $.29 \pm .03^{\mathrm{A}}$ & $.33 \pm .05^{\mathrm{A}}$ \\
\hline \multicolumn{4}{|l|}{ Urinary $\mathrm{N}\left(\mathrm{g} \mathrm{d}^{-1}\right)$ : } \\
\hline Lucerne hay & $3.04 \pm .31^{\mathrm{Y}, * * *}$ & $5.21 \pm .34^{\mathrm{X}, * * *}$ & $6.03 \pm .57^{\mathrm{X}, \star \star \star}$ \\
\hline Oaten hay & $1.12 \pm .121^{\mathrm{Y}}$ & $1.39 \pm .24^{\mathrm{Y}}$ & $2.35 \pm .24^{\mathrm{x}}$ \\
\hline \multicolumn{4}{|l|}{ Fecal N $\left(\mathrm{g} \mathrm{d}^{-1}\right)$ : } \\
\hline Lucerne hay & $1.68 \pm .21^{\mathrm{Y}, \star * *}$ & $2.71 \pm .13^{\mathrm{X}, * * *}$ & $3.39 \pm .43^{\mathrm{X}, \star *}$ \\
\hline Oaten hay & $.55 \pm .07^{\mathrm{B}}$ & $.85 \pm .11^{\mathrm{B}}$ & $1.60 \pm .22^{\mathrm{A}}$ \\
\hline \multicolumn{4}{|l|}{ Apparent $\mathrm{N}$ digestibility (\%): } \\
\hline Lucerne hay & $75 \pm 1^{\mathrm{A}, * * *}\left({ }^{* * *}\right)$ & $76 \pm 1^{\mathrm{A}, * * *}$ & $71 \pm 2^{\mathrm{A}, * * *}$ \\
\hline Oaten hay (from forage) ${ }^{\mathrm{a}}$ & $57 \pm 4^{\mathrm{A}}\left(33 \pm 7^{\mathrm{B}}\right)$ & $49 \pm 5^{\mathrm{A}}$ & $56 \pm 3^{\mathrm{A}}$ \\
\hline \multicolumn{4}{|l|}{$\mathrm{N}$ balance $\left(\mathrm{g} \mathrm{d}^{-1}\right)$ : } \\
\hline Lucerne hay & $1.9 \pm .3^{\mathrm{A}, \star * *}$ & $3.4 \pm .3^{\mathrm{B}, \star \star \star}$ & $2.2 \pm .4^{\mathrm{A}, \star * \star}$ \\
\hline Oaten hay & $-.4 \pm .1^{\mathrm{A}}$ & $-.5 \pm .3^{\mathrm{A}}$ & $-.2 \pm .2^{\mathrm{A}}$ \\
\hline \multicolumn{4}{|l|}{$\mathrm{N}$ balance $\left(\mathrm{mg} \mathrm{kg}^{-.75} \mathrm{~d}^{-1}\right)$ : } \\
\hline Lucerne hay & $462 \pm 54^{\mathrm{A}, * * *}$ & $570 \pm 50^{\mathrm{A}, * * *}$ & $194 \pm 38^{\mathrm{B}, * * *}$ \\
\hline Oaten hay & $-103 \pm 26^{\mathrm{A}}$ & $-57 \pm 31^{\mathrm{A}}$ & $-19 \pm 14^{\mathrm{B}}$ \\
\hline
\end{tabular}

chopped lucerne hay (Table 4), the YAF and weaned kangaroos had $\mathrm{N}$ intakes $\left(\mathrm{mg} \mathrm{kg} \mathrm{kg}^{-0.75} \mathrm{~d}^{-1}\right)$ that were 1.6-1.9 times those by mature females, largely reflecting differences in their overall feed intakes (Table 3). Moreover, on this high-quality diet, the juveniles retained more dietary $\mathrm{N}\left(\mathrm{mg} \mathrm{kg}^{-0.75} \mathrm{~d}^{-1}\right)$ than did the mature, nonlactating females (Table 4 ) and gained $43-55$ g body mass $\mathrm{d}^{-1}$ (Table 3 ). This level of growth was consistent with that seen in juvenile red kangaroos under ideal conditions (Sharman et al. 1964; Frith and Calaby 1969). However, lack of data on growth and $\mathrm{N}$ retention by other marsupial young after pouch exit prevents comparisons with other species.

Growth and $\mathrm{N}$ balance were compromised in the juvenile red kangaroos on the poor-quality chopped oaten hay (Table 2). Munn and Dawson (2003a) discussed the impact of the lower feed intakes on the energetics of these kangaroos. Briefly, digestible energy intake by the YAF, weaned, and adults on chopped oaten hay were just $55 \%, 58 \%$, and $68 \%$, respectively, of their maintenance energy requirements (Munn and Dawson 2003a). Energy and N metabolism are intimately linked (MacRae and Lobley 1986; White et al. 1988; Chowdhury and Ørskov 1997), and there was a significant relationship between $\mathrm{N}$ balance and digestible energy intake by our kangaroos (Fig.
3). On average, the YAF and weaned kangaroos were in negative $\mathrm{N}$ balance at digestible energy intakes of less than 292 and 259 $\mathrm{kJ} \mathrm{kg}^{-0.75} \mathrm{~d}^{-1}$, respectively. This was partially explained by their low $\mathrm{N}$ intakes on the oaten hay diet (Table 4) but was also related to their high endogenous $\mathrm{N}$ losses, particularly as EUN (Table 6).

In animals that are sufficiently well nourished, EUN is mainly a function of basal energy metabolism (Smuts 1935; Robbins 1993; Hume 1999). In mammals, the energy costs associated with protein synthesis form a consistent component of basal metabolic rate (see MacRae and Lobley 1986). The by-products of protein synthesis, mainly urea, are excreted in urine, contributing largely to EUN. Consequently, EUN generally increases with increasing basal metabolic rate (Smuts 1935; Robbins 1993; Hume 1999; Bradshaw and Bradshaw 2001). Indeed, the YAF red kangaroos in our study had EUN losses (mg truly digestible $\mathrm{N} \mathrm{kg}^{-0.75} \mathrm{~d}^{-1}$ ) that were 2.7 times those by mature, nonlactating females. This is consistent with the YAF having a higher resting metabolic rate (Munn and Dawson 2001). These results must be viewed with caution, however, because EUN is also elevated when animals are energy undernourished, as was the case for our kangaroos on chopped oaten hay (Fig. 3; Munn 
Table 5: Excretion of nondietary fecal $\mathrm{N}$ and truly digestible $\mathrm{N}$ intake by young-at-foot (YAF), weaned, and adult red kangaroos fed chopped lucerne and oaten hays

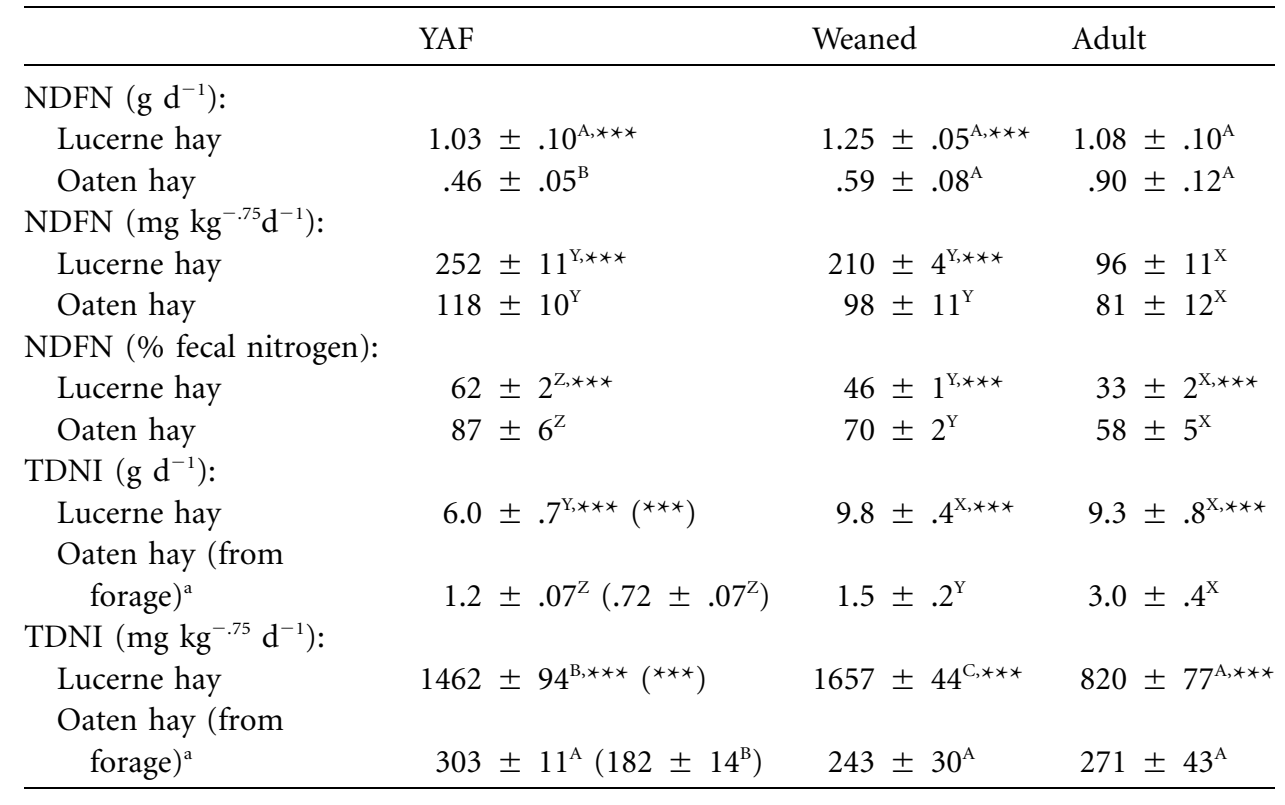

Note. $\mathrm{NDFN}=$ nondietary fecal nitrogen; TDNI $=$ truly digestible nitrogen intake. Within a row, means \pm SEM bearing different superscripts are significantly different $(\mathrm{A}-\mathrm{C}, \mathrm{P}<0.05 ; \mathrm{X}-\mathrm{Z}, P<0.01)$. Asterisks indicate significant differences between diets within ages.

${ }^{a}$ TDNI from forage was estimated assuming a milk-N digestibility of $95 \%$.

$* * * \quad P<0.001$.

and Dawson 2003a). Macropodid marsupials carry little body fat (Tribe and Peel 1963), and protein is likely the main source for endogenous energy metabolism when required (White et al. 1988). Notably, the YAF red kangaroos in our study had EUN losses that were three times that predicted (sensu Bradshaw and Bradshaw 2001) from their higher resting metabolic rate alone (ca. $300 \mathrm{~kJ} \mathrm{~kg}^{-0.75} \mathrm{~d}^{-1}$; Munn and Dawson 2001). EUN by our weaned red kangaroos was comparable to that previously reported for subadults (Brown 1968) but was still 1.4 times that expected from their resting metabolic rate (ca. $316 \mathrm{~kJ} \mathrm{~kg}^{-0.75} \mathrm{~d}^{-1}$; Munn and Dawson 2001). Our mature female, nonlactating red kangaroos, on the other hand, produced an amount of EUN (63 mg EUN kg-0.75 $\mathrm{d}^{-1}$; Table 6) that was similar to that predicted $\left(60 \mathrm{mg}\right.$ EUN kg $\mathrm{kg}^{-0.75} \mathrm{~d}^{-1}$; Bradshaw and Bradshaw 2001) from their basal metabolic rate (ca. 200 $\mathrm{kJ} \mathrm{kg}^{-0.75} \mathrm{~d}^{-1}$; Dawson et al. 2000).

In addition to their urinary $\mathrm{N}$ losses associated with a higher resting metabolic rate (compared with adults), the high EUN losses by our juvenile red kangaroos may also be related to higher rates of protein turnover for growth. Little is known about protein turnover by young marsupials after pouch exit, but the YAF and weaned red kangaroos excreted more urinary $\mathrm{N}\left(\mathrm{mg} \mathrm{kg}^{-0.75} \mathrm{~d}^{-1}\right)$ on the high-quality lucerne hay than did the mature, nonlactating females (Fig. 2). Nonetheless, the extent to which the high EUN of these juveniles was a consequence of growth-related protein turnover (on chopped lucerne hay) or protein catabolism in response to energy deficiency (on chopped oaten hay) could not be determined from this study. Consequently, we were also unable to reliably estimate the $\mathrm{N}$

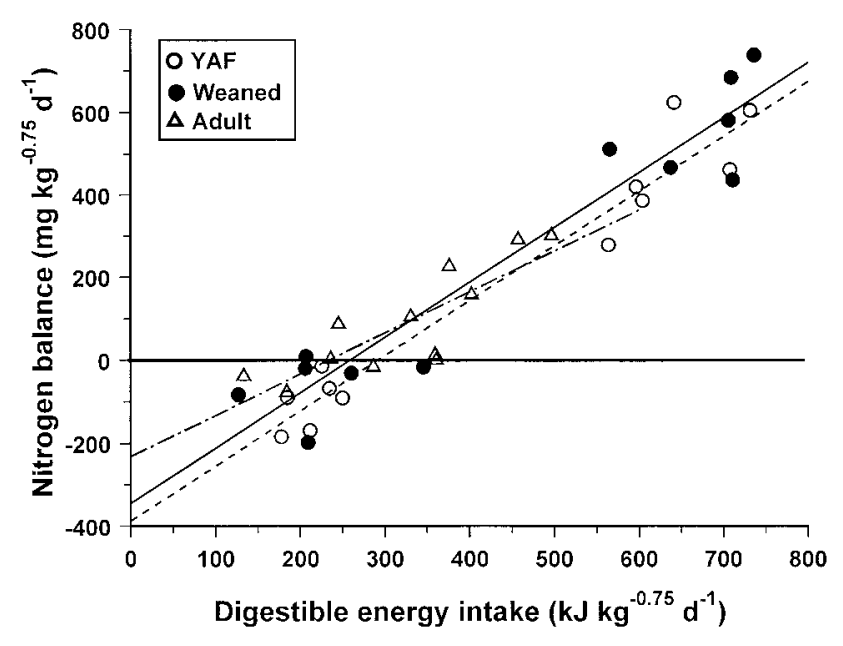

Figure 3. Nitrogen balance $\left(\mathrm{mg} \mathrm{kg}^{-0.75} \mathrm{~d}^{-1}\right)$ as a function of digestible energy intake $\left(\mathrm{kJ} \mathrm{kg}^{-0.75} \mathrm{~d}^{-1}\right)$. Dashed line, YAF; $y=1.3 x-388( \pm 48)$, $r^{2}=0.95, \quad F=178, \mathrm{df}=11, P<0.001$. Solid line, weaned; $y=$ $1.3 x-345( \pm 66), r^{2}=0.91, F=105, \mathrm{df}=11, P<0.001$. Dashed and dotted line, adult; $y=1.0 x-232( \pm 71), r^{2}=0.69, F=22, \mathrm{df}=$ $11, P<0.001$. 
Table 6: Endogenous urinary nitrogen (EUN) excretion by some macropodid marsupials, including young-atfoot (YAF), weaned, and adult red kangaroos

\begin{tabular}{llccl}
\hline & Latin Name & $\begin{array}{l}\text { Body Mass } \\
(\mathrm{kg})\end{array}$ & $\begin{array}{l}\mathrm{EUN} \\
\left(\mathrm{mg} \mathrm{kg}^{-0.75} \mathrm{~d}^{-1}\right)\end{array}$ & Source \\
\hline Quokka & Setonix brachyurus & $2.0-3.6$ & 43 & Brown 1968 \\
Black-footed rock wallaby & Petrogale lateralis & 3.9 & 49 & Brown 1968 \\
Tammar wallaby & Macropus eugenii & $4.2-5.3$ & $33-58$ & Barker 1968; Hume 1977 \\
Euro & Macropus robustus & $8.5-19.7$ & $31-32$ & Brown and Main 1967; \\
& erubescens & & & Brown 1968 \\
Red kangaroos & Macropus rufus & 6.4 & 170 & This study \\
$\quad$ YAF & 11 & 89 & This study \\
Weaned & 14 & 87 & Brown 1968 \\
Subadults & 26 & 63 & This study \\
Mature females & & &
\end{tabular}

requirements for maintenance or growth for our juvenile red kangaroos.

Maintenance $\mathrm{N}$ requirements (MNR) of mature herbivores are determined largely by their endogenous $\mathrm{N}$ losses, both urinary and fecal (Hume 1999). MNR is typically measured as the level of $\mathrm{N}$ intake required to maintain zero $\mathrm{N}$ balance (Fig. 4; Robbins 1993). As such, increases in EUN associated with protein catabolism in response to energy deficiency can lead to overestimates of MNR. For this reason, studies designed to measure MNR are usually based on a series of isoenergetic diets varying only in $\mathrm{N}$ content to ensure that animals fed lowprotein diets are also not energy deprived. We did not use isoenergetic diets (Table 1), but our mature female red kangaroos had EUN losses no higher than expected from their basal metabolic rate (Bradshaw and Bradshaw 2001). Moreover, the mature females did not lose significant body mass (Table 2) on the low-protein diet (i.e., chopped oaten hay) and remained at zero $\mathrm{N}$ balance (Table 4). Therefore, we were able to estimate the MNR of mature female, nonlactating red kangaroos as $392 \mathrm{mg}$ dietary $\mathrm{N}$ or $317 \mathrm{mg}$ truly digestible $\mathrm{N} \mathrm{kg}^{-0.75}$ $\mathrm{d}^{-1}$ (Fig. 4). However, these estimates are based on only two diets and should be confirmed by experiments using a series of isoenergetic diets with varying $\mathrm{N}$ contents.

The MNR (truly digestible $\mathrm{N}$ ) of the mature female red kangaroos in our study was higher than that previously reported for large (>10 kg) macropodid marsupials (range 160-270 mg truly digestible $\mathrm{N} \mathrm{kg}^{-0.75} \mathrm{~d}^{-1}$; Hume 1999) but was still lower than that reported for herbivorous eutherians by around $50 \%$ (Hume 1999; Robbins 1993). Putatively, the lower MNR of marsupials compared with eutherians is related to their lower basal metabolic rates (Dawson and Hulbert 1970) and, consequently, lower EUN losses (see Robbins 1993). White et al. (1988) and Bradshaw and Bradshaw (2001), however, argued that marsupials may also have fundamentally lower rates of protein turnover compared with eutherians.

Endogenous $\mathrm{N}$ losses as NDFN were also higher among the juvenile red kangaroos compared with adults. However, on chopped lucerne hay, some of the mature females excreted comparably high levels of $\mathrm{N}$ in their feces (per unit of feed intake), potentially levering the slope of the adult curve to yield a lower $y$-intercept (i.e., NDFN; Fig. 1). This may be a consequence of using just two experimental diets, but it may also be related to juveniles actively absorbing more $\mathrm{N}$ from the highquality forage (per unit of intake) compared with adults. Knott et al. (2004), for example, found high surface enlargement in the duodenum of juvenile muskoxen (Ovibos moschatus) and reindeer (Rangifer tarandus), possibly enhancing digestion and absorption of protein from milk and forage. Further investigation is required to resolve this issue. Regardless, we found that, on average, the YAF and weaned kangaroos produced 1.5-

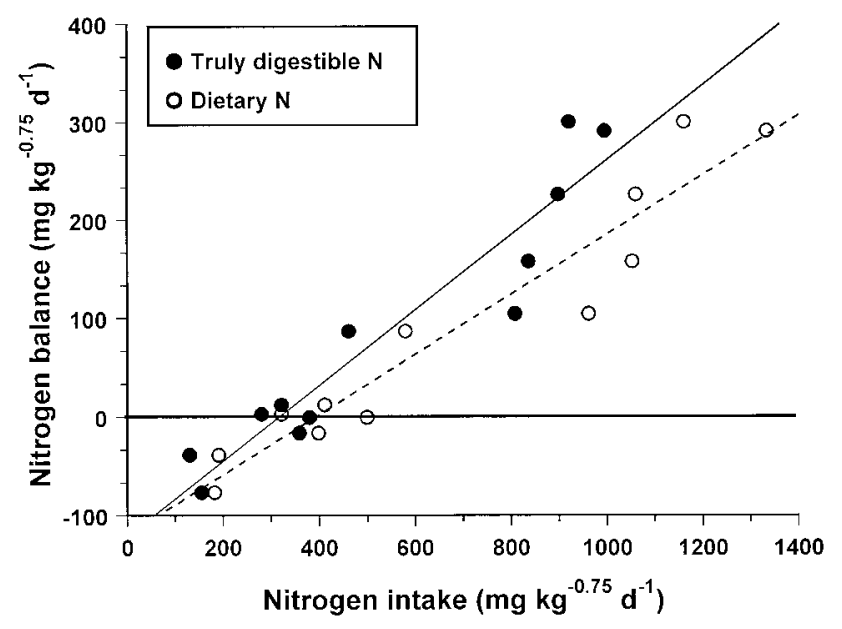

Figure 4. Nitrogen balance $\left(\mathrm{mg} \mathrm{kg}^{-0.75} \mathrm{~d}^{-1}\right)$ as a function of $\mathrm{N}$ intake $\left(\mathrm{mg} \mathrm{kg}^{-0.75} \mathrm{~d}^{-1}\right)$ by mature, nonlactating female red kangaroos. Solid line, $\mathrm{N}$ balance $=0.38$ truly digestible $\mathrm{N}$ intake $-121( \pm 26), r^{2}=$ $0.89, F=88, \mathrm{df}=11, P<0.001$. Dashed line, $\mathrm{N}$ balance $=0.31 \mathrm{di}-$ etary $\mathrm{N}$ intake $-119( \pm 23), r^{2}=0.91, F=111$, df $=11, P<0.001$. 
Table 7: Excretion of nondietary fecal nitrogen (NDFN) by some macropodid marsupials, including young-at-foot (YAF), weaned, and adult female red kangaroos

\begin{tabular}{|c|c|c|c|c|}
\hline & Latin Name & $\begin{array}{l}\text { Body Mass } \\
(\mathrm{kg})\end{array}$ & $\begin{array}{l}\text { NDFN } \\
\left(\mathrm{g} \mathrm{N} \mathrm{kg}^{-1} \mathrm{DMI}\right)\end{array}$ & Source \\
\hline Parma wallaby & Macropus parma & $3.7-3.9$ & 5.7 & Hume 1986 \\
\hline Tammar wallaby & Macropus eugenii & $4.2-5.3$ & 4.8 & Barker 1968; Hume 1977 \\
\hline Euro & $\begin{array}{l}\text { Macropus robustus } \\
\text { erubescens }\end{array}$ & $8.5-19.7$ & $2.7-3.8$ & $\begin{array}{l}\text { Brown and Main 1967; } \\
\text { Hume } 1974\end{array}$ \\
\hline Red kangaroos & Macropus rufus & & & \\
\hline YAF & & 6.4 & 4.4 & This study \\
\hline Weaned & & 11 & 3.8 & This study \\
\hline Mature females & & 26 & 2.6 & This study \\
\hline
\end{tabular}

Note. DMI $=$ dry matter intake.

1.7 times more NDFN ( $\mathrm{g} \mathrm{kg} \mathrm{DMI}^{-1}$ ) than did the mature females, though there was considerable variation around the derived intercepts (Fig. 1) and statistical comparisons were not possible (see "Results"). Nonetheless, these data are consistent with smaller herbivores generally having higher NDFN losses compared with larger animals (Table 7), though the reasons for this are unclear (Hume 1999).

Among grazing ruminants, $80 \%-90 \%$ of NDFN is bacterial residue (Mason 1969; Robbins 1993), but the abrasive action of fibrous roughage may also increase $\mathrm{N}$ loss as intestinal cellular debris. Notably, on the poor-quality oaten hay, $70 \%-87 \%$ of the YAF and weaned kangaroos' total fecal $\mathrm{N}$ was NDFN, compared with just $58 \%$ in the adult females (Table 5). Consequently, on oaten hay, the YAF lost $64 \%$ of their TDNI from forage as NDFN (Table 5). By weaning age, the situation had improved, but juveniles still lost $40 \%$ of their TDNI as NDFN, compared with just $30 \%$ by the mature females. Thus, under dry conditions and when only low- $\mathrm{N}$, high-fiber forage is available (Dawson and Ellis 1994), juvenile red kangaroos may be expected to suffer greater $\mathrm{N}$ losses $\left(\mathrm{mg} \mathrm{kg}^{-0.75}\right)$ than mature females, compromising their growth and survival.

Interestingly, some of our kangaroos were able to select diets that were higher in $\mathrm{N}$ content than was available from the average feed offered and also higher than that selected by other animals fed similar forage. On chopped oaten hay, for example, some weaned kangaroos were able to select a diet with double the $\mathrm{N}$ content of that selected by others (see Fig. 1). Although we could not draw firm conclusions from our results, the apparent selective ability of some kangaroos warrants further investigation. Such differences in selectivity suggest that some individuals are better at sorting and ingesting diets of higher $\mathrm{N}$ content, which may be especially important for young kangaroos in the field. Moreover, our data support observations that forage quality is the best predictor of body condition in red kangaroos in the field, particularly for juveniles (Shepherd 1987; Moss and Croft 1999). It is apparent that forage fiber and $\mathrm{N}$ content are important for the growth and survival of juvenile red kangaroos. During good environmental conditions, when sufficient fresh forage is available, this may not be a problem for juveniles. The YAF red kangaroos on low-fiber, high- $\mathrm{N}$ forage (i.e., chopped lucerne hay) were able to sustain growth at levels comparable to those under ideal conditions, even without receiving any milk (see Munn and Dawson 2003b). YAF would normally receive some milk from their mothers, though milk intake declines rapidly at this stage as forage intake increases (Cork and Dove 1989; Dove and Cork 1989). More importantly, during poor environmental conditions, lactation by red kangaroos is truncated (Newsome 1964a, $1964 b$ ) and the YAF must contend with whatever forage is available. Neither the YAF nor the weaned red kangaroos in our study could sustain growth on the high-fiber, low- $\mathrm{N}$ chopped oaten hay (Table 2); they had high endogenous $\mathrm{N}$ losses and were in negative $\mathrm{N}$ balance. Conversely, the mature, nonlactating females on chopped oaten hay remained at zero $\mathrm{N}$ balance and were able to maintain body mass at levels that were not significantly different from those fed chopped lucerne (Table 2). On chopped oaten hay, the mature females had TDNIs (271 mg kg $\mathrm{mg}^{-0.75} \mathrm{~d}^{-1}$; Table 5) at the upper range of the MNRs of large ( $>10 \mathrm{~kg}$ body mass) macropodids generally (Hume 1999), with this level of intake being $86 \%$ of their MNR (truly digestible N) estimated here. Notably, mature females make up the bulk of red kangaroo populations and have the lowest drought-related mortalities of any cohort (Dawson 1995; McCullough and McCullough 2000).

\section{Acknowledgments}

This research was in part funded by a grant from the Australian Research Council to T.J.D. Kangaroos were held under a licence from the New South Wales National Parks and Wildlife Service (B1756), and the University of New South Wales Animal Care and Ethics Committee (ACEC 99/18) gave approval for this project. We thank Dr. Fred Stoddard and the Plant Breeding 
Institute, Department of Crop Sciences, University of Sydney, for the use of their Leco CHN-1000 elemental analyzer. Fiber samples were analyzed by Mandy Yialeloglou of the Commonwealth Scientific and Industrial Research Organisation Sustainable Ecosystems using their ANKOM. We thank Dr. Joanne Holloway for her assistance with experiments and to all the animal caregivers who participated in this project, especially Anne Williams.

\section{Literature Cited}

Barker R.D. 1987. The diet of herbivores in the sheep rangelands. Pp. 69-83 in G. Caughley, N. Shepherd, and J. Short, eds. Kangaroos: Their Ecology and Management in Sheep Rangelands of Australia. Cambridge University Press, Cambridge.

Barker S. 1968. Nitrogen balance and water intake in the Kangaroo Island wallaby, Protemnodon eugenii (Desmarest). Aust J Exp Biol Med Sci 46:17-32.

Bayliss P. 1985. The population dynamics of red and western grey kangaroos in arid New South Wales, Australia. I. Population trends and rainfall. J Anim Ecol 54:111-125.

Bosshardt D.K. and R.H. Barnes. 1946. The determination of metabolic faecal nitrogen and protein digestibility. J Nutr 31: 13-21.

Bradshaw F.J. and S.D. Bradshaw. 2001. Maintenance nitrogen requirement of an obligate nectarivore, the honey possum, Tarsipes rostratus. J Comp Physiol B 171:59-67.

Brody S. 1945. Bioenergetics and Growth: With Special Reference to the Efficiency Complex in Domestic Animals. Reinhold, New York.

Brown G.D. 1968. The nitrogen and energy requirements of the euro (Macropus robustus) and other species of macropod marsupials. Proc Ecol Soc Aust 3:106-112.

Brown G.D. and A.R. Main. 1967. Studies on marsupial nutrition. V. The nitrogen requirements of the euro (Macropus robustus). Aust J Zool 15:7-27.

Chowdhury S.A. and E.R. Ørskov. 1997. Protein energy relationships with particular references to energy undernutrition: a review. Small Ruminant Res 26:1-7.

Cork S.J. 1994. Digestive constraints on the dietary scope in small and moderately-small mammals: how much do we really understand? Pp. 337-369 in D.J. Chivers and P. Langer, eds. The Digestive System in Mammals: Food, Form and Function. Cambridge University Press, Cambridge.

Cork S.J. and H. Dove. 1989. Lactation in the tammar wallaby (Macropus eugenii). II. Intake of milk components and maternal allocation of energy. J Zool (Lond) 219:399-409.

Dawson T.J. 1995. Kangaroos: Biology of the Largest Marsupials. University of New South Wales Press, Sydney.

Dawson T.J., C.E. Blaney, A.J. Munn, A. Krockenberger, and S.K. Maloney. 2000. Thermoregulation by kangaroos from mesic and arid habitats: influence of temperature on routes of heat loss in eastern grey kangaroos (Macropus giganteus) and red kangaroos (Macropus rufus). Physiol Biochem Zool 73:374-381.

Dawson T.J., M.J.S. Denny, E.M. Russell, and B. Ellis. 1975. Water usage and diet preferences of free ranging kangaroos, sheep and feral goats in the Australian arid zone during summer. J Zool (Lond) 177:1-23.

Dawson T.J. and B.A. Ellis. 1994. Diets of mammalian herbivores in Australian arid shrublands: seasonal effects on overlap between red kangaroos, sheep and rabbits and on dietary niche breadths and electivities. J Arid Environ 26:257-271.

Dawson T.J. and A.J. Hulbert. 1970. Standard metabolism, body temperature, and surface areas of Australian marsupials. Am J Physiol 218:1233-1238.

Demment M.W. and P.J. Van Soest. 1985. A nutritional explanation for body-size patterns of ruminant and nonruminant herbivores. Am Nat 125:641-672.

Dove H. and S.J. Cork. 1989. Lactation in the tammar wallaby (Macropus eugenii). I. Milk consumption and the algebraic description of the lactation curve. J Zool (Lond) 219:385397.

Foley W.J. and I.D. Hume 1987. Nitrogen requirements and urea metabolism in two arboreal marsupials, the greater glider (Petauroides volans) and the brushtail possum (Trichosurus vulpecular) fed eucalyptus foliage. Physiol Zool 60: 241-250.

Frith H.J. and J.H. Calaby. 1969. Kangaroos. Cheshire, Melbourne.

Hayssen V. and R.C. Lacy. 1985. Basal metabolic rates in mammals: taxonomic differences in the allometry of BMR and body mass. Comp Biochem Physiol A 81:741-754.

Hume I.D. 1974. Nitrogen and sulphur retention and fibre digestion by euros, red kangaroos and sheep. Aust J Zool 22: 13-23.

2. 1977. Maintenance nitrogen requirements of the macropodid marsupials Thylogale theits, red-necked pademelon, and Macropus eugenii, tammar wallaby. Aust J Zool 25:407-417.

- 1986. Nitrogen metabolism in the parma wallaby, Macropus parma. Aust J Zool 34:147-155.

-1 1999. Marsupial Nutrition. Cambridge University Press, Cambridge.

Knott K.K., P.S. Barboza, R.T. Bowyer, and J.E. Blake. 2004. Nutritional development of feeding strategies in arctic ruminants: digestive morphometry of reindeer, Rangifer tarandus, and muskoxen, Ovibos moschatus. Zoology 107:315333.

Low B. 1979. The predictability of rain and the foraging patterns of red kangaroo (Megaleia rufa) in central Australia. J Arid Environ 2:61-76.

MacRae J.C. and G.E. Lobley. 1986. Interactions between energy and protein. Pp. 367-385 in L.P. Milligan, W.L. Grovum, and 
A. Dobson, eds. Control of Digestion and Metabolism in Ruminants. Prentice Hall, Englewood Cliffs, NJ.

Mason V.C. 1969. Some observations on the distribution and origin of nitrogen in sheep faeces. J Agric Sci 73:99-111.

McCullough D.R. and Y. McCullough. 2000. Kangaroos in Outback Australia: Comparative Ecology and Behavior of Three Coexisting Species. Columbia University Press, New York.

McIntosh D.L. 1966. The digestibility of two roughages and the rates of passage of their residues by the red kangaroo, Megaleia rufa (Desmarest), and the merino sheep. CSIRO Wildl Res 11:125-135.

Moss G.L. and D.B. Croft. 1999. Body condition of the red kangaroo (Macropus rufus) in arid Australia: the effect of environmental condition, sex and reproduction. Aust J Ecol 24:97-109.

Munn A.J. and T.J. Dawson. 2001. Thermoregulation in juvenile red kangaroo (Macropus rufus) after pouch exit: higher metabolism and evaporative water requirements. Physiol Biochem Zool 74:917-927.

- 2003a. Energy requirements of the red kangaroos (Macropus rufus): impacts of age, growth and body size in a large desert-dwelling herbivore. J Comp Physiol B 173: 575-582.

- 2003b. How important is milk for near-weaned red kangaroos (Macropus rufus) fed different forages? J Comp Physiol B 173:141-148.

Newsome A.E. 1964a. Anoestrus in the red kangaroo, Megaleia rufa (Desmarest). Aust J Zool 12:6-17.

-1964b. Oestrus in the lactating red kangaroo, Megaleia rufa (Desmarest). Aust J Zool 12:315-321.

Newsome A.E., D.R. Stephens, and A.K. Shipway. 1967. Effect of a long drought on the abundance of red kangaroos in central Australia. CSIRO Wildl Res 12:1-8.

Penning P.D., I.M. Penning, and T.T. Treacher. 1977. The effect of temperature and method of feeding on the digestibility of two milk substitutes and on the performance of lambs. J Agric Sci 88:579-589.

Robbins C.T. 1993. Wildlife Feeding and Nutrition. Academic Press, New York.
Robertson G. 1986. The mortality of kangaroos in drought. Aust Wildl Res 13:349-354.

Robertson J.B. and P.J. Van Soest. 1981. The detergent system of analysis and its application to human foods. Pp. 123-158 in W.P.T. James and O. Theander, eds. The Analysis of Dietary Fibre in Food. Dekker, New York.

Roy J.H.B. 1980. The Calf. 4th ed. Butterworth, London.

Sharman G.B., H.J. Frith, and J.H. Calaby. 1964. Growth of the pouch young, tooth eruption and age determination in the red kangaroo, Megaleia rufa. CSIRO Wildl Res 9:20-49.

Shepherd N. 1987. Condition and recruitment of kangaroos. Pp. 135-158 in G. Caughley, N. Shepherd, and J. Short, eds. Kangaroos: Their Ecology and Management in the Sheep Rangelands of Australia. Cambridge University Press, Cambridge.

Smith A.P. and S.W. Green. 1987. Nitrogen requirements of the sugar glider (Petaurus breviceps), an omnivorous marsupial, on a honey-pollen diet. Physiol Zool 60:82-92.

Smuts D.B. 1935. The relation between the basal metabolism and the endogenous nitrogen metabolism with particular reference to the estimation of the maintenance requirement of protein. J Nutr 9:403-433.

Ternouth J.H., I.J.F. Stobo, J.H.B. Roy, and A.W. Beattie. 1985. The effect of milk substitute concentration upon the intake, digestion and growth of calves. Anim Prod 41:151-159.

Tribe D.E. and L. Peel. 1963. Body composition of the kangaroos (Macropus sp.). Aust J Zool 11:273-289.

Van Soest P.J., J.B. Robertson, and B.A. Lewis. 1991. Methods for dietary fibre, neutral detergent fibre, and non-starch polysaccharides in relation to animal nutrition. J Dairy Sci 74: 3583-3597.

White R.G., I.D. Hume, and J.V. Nolan. 1988. Energy expenditure and protein turnover in three species of wallabies (Marsupialia: Macropodidae). J Comp Physiol B 158:237246.

Williams A. and R. Williams. 1999. Caring for Kangaroos and Wallabies. Kangaroo Press, East Roseville, New South Wales.

Zar J.H. 1999. Biostatistical Analysis. 4th ed. Prentice Hall, Upper Saddle River, NJ. 